\title{
POLA HUBUNGAN PATRONASE \\ DALAM BIROKRASI PEMERINTAHAN DAERAH \\ KABUPATEN BANDUNG BARAT
}

\author{
Dadang Sufianto \\ dadang.sufi54@gmail.com \\ Dosen Magister Ilmu Pemerintahan \\ Universitas Jenderal Achmad Yani, Cimahi
}

\begin{abstract}
Abstrak
Penelitian ini dilakukan pada tahun 2017 sebagai lanjutan dari penelitian serupa yang dilakukan di Kota Cimahi pada tahun 2016. Pendekatan yang digunakan adalah pendekatan kualitatif. Sedangkan tujuannnya untuk mengetahui keberadaan pola hubungan patronase dalam birokrasi pemerintahan daerah Kabupaten Bandung Barat, latar belakangnya, dan dampaknya terhadap kinerja pemerintahan daerah.

Dari hasil penelitian diketahui hal-hal sebagai berikut; Pada birokrasi pemerintahan daerah Kabupaten Bandung Barat terdapat pola hubungan patronase antara Bupati (sebagai patron) dengan para pejabat tertentu (sebagai klien) yang diketahui dari pengembangan karier. Faktor-faktor yang melatar-belakanginya yaitu faktor politik berupa penyelenggaraan pilkada langsung, faktor budaya untuk saling menitipkan di antara kedua-belah pihak, dan faktor kinerja pegawai. Keberadaan pola hubungan patronase tidak berdampak negatif terhadap capaian kinerja pemda KBB.
\end{abstract}

Kata Kunci: Patronase, Birokrasi, Pemda

\section{Pendahuluan}

Salah satu fenomena pemerintahan yang menarik untuk diteliti adalah adanya pola hubungan patronase dalam birokrasi pemerintahan daerah. Pola hubungan ini perlu dipelajari agar dapat dikelola dengan tepat dan bijak. Ten Dam (di Kausar, 2009: 163) berpendapat bahwa ada pola hubungan patronase dalam pemerintah daerah. Hal yang sama juga dinyatakan Mardiyanto sebagai Menteri Dalam Negeri RI 2007-2009 (dalam Kausar, 2009: ix) bahwa budaya patron-klien (patronase) dalam birokrasi pemerintah daerah adalah realitas yang tak terbantahkan.

Secara teoritis, pola hubungan patronase dalam birokrasi pemerintahan sulit untuk diterima keberadaannya karena tidak sesuai dengan sifat birokrasi yang memiliki pola hubungan birokratis. Pola hubungan patronase bersifat personal, tidak formal, emosional, dan prosedural; sedangkan pola hubungan birokratis bersifat impersonal, formal, rasional, dan prosedural. Oleh karena itu, pola hubungan patronase dipandang 
sebagai sesuatu yang dapat mengganggu pencapaian kinerja pemerintah daerah, terutama dalam pelayanan publik.

Penelitian tentang fenomena ini diharapkan dapat dilakukan di berbagai lokasi dengan karakter budaya yang berbeda, misalnya di daerah perkotaan, pinggiran kota, dan pedesaan untuk mendapatkan hasil yang representatif dalam pengayaan ilmu pemerintahan.

Setelah penelitian dilakukan oleh peneliti di Kota Cimahi pada tahun 2016, kini penelitian dilakukan di Kabupaten Bandung Barat. Dengan latar belakang tersebut, penelitian ini diberi judul "Pola hubungan patronase dalam birokrasi pemerintahan daerah Kabupaten Bandung Barat."

Masalah penelitian dirumuskan sebagai berikut:

1) apakah dalam birokrasi pemerintahan daerah Kabupaten Bandung Barat terdapat pola hubungan patronase;

2) apa latar-belakang terjadinya pola hubungan patronase tersebut; dan

3) apa dampak keberadaan pola hubungan patronase tersebut terhadap kinerja pemerintah daerah.

\section{Metode Penelitian}

Penelitian ini dirancang dengan pendekatan kualitatif-fenomenologis karena tidak dimaksudkan untuk menguji teori (verifikasi teori), melainkan untuk mendapatkan gambaran dan pemahaman mendalam tentang fenomena yang diteliti secara alami. Sedangkan teknik penyajian hasil penelitian yang dipilih adalah 'deskriptif-analitis,' yaitu penggambaran obyek faktual yang dianalisis secara kualitatif.

Objek penelitian adalah 'tanda-tanda pola hubungan patronase' dalam birokrasi pemerintahan daerah Kabupaten Bandung Barat (disingkat KBB). Subyek penelitian adalah Bupati dan beberapa pejabat pemerintahan daerah KBB lainnya.

Data yang dikumpulkan terdiri dari data primer dan data sekunder. Data primer diperoleh dari pengamatan dan wawancara dengan informan yang terdiri dari pejabat setempat. Sedangkan data sekunder diperoleh dari penelaahan dokumen. Wawancara mendalam dilakukan untuk mengeksplorasi kedalaman informasi yang tidak terlihat dan tidak dapat diamati seperti karakter, keyakinan, sistem nilai, kepentingan politik, motif dan emosi pribadi. Sedangkan instrumen pengumpulan data adalah peneliti sendiri dengan menggunakan panduan wawancara yang dipersiapkan sebelumnya. 
Dalam mengantisipasi kemungkinan ancaman terhadap validitas data, peneliti melakukan pencatatan data secara rinci dan selengkap mungkin; konfirmasi kepada informan (cek anggota) jika keraguan ditemukan; dan check-recheck setiap data yang dikumpulkan. Agar mendapatkan tingkat kepercayaan yang tinggi dari data, peneliti menggunakan tiga (3) jenis triangulasi, yaitu triangulasi sumber, metode, dan teori. Triangulasi sumber dilakukan dengan membandingkan data/informasi dari satu sumber dengan data/informasi yang ditemukan dari sumber lain. Triangulasi metode dilakukan dengan membandingkan temuan observasi, wawancara dan review dokumen. Triangulasi teori dilakukan dengan membandingkan draft proposisi yang telah dibuat dengan teori/konsep atau penjelasan patokan lain yang relevan dengan tujuan penelitian

\section{Hasil Penelitian Dan Pembahasan}

Penelitian tentang fenomena pola hubungan patronase sudah dilakukan di beberapa daerah dengan basis yang berbeda. Dari Kausar (2009: 21) diperoleh informasi tentang penelitian yang telah dilakukan di Indonesia, yaitu:

1) Penelitian pola patronase berbasis kehidupan bangsawan (karaeng-ata) dan penguasaan tanah di Sulawesi Selatan yang dilakukan oleh Mudyono pada tahun 1978, Effendi pada tahun 1981, dan Fatmawati pada tahun 1996.

2) Penelitian pola hubungan patronase berbasis mata pencaharian nelayan (punggawasawi) di Sulawesi Selatan yang dilakukan oleh Sallatang 1982.

3) Penelitian pola patronase berbasis pertanian (petani kecil- besar) di Jawa Barat yang dilakukan Rusidi 1989;

4) Penelitian pola hubungan patronase berbasis birokrasi pemerintahan di Tulang Bawang-Lampung dilakukan Kausar 2004-2005;

5) Penelitian pola hubungan patronase dalam birokrasi pemeritahan daerah Kota Cimahi oleh Dadang Sufianto dkk tahun 2016.

Setelah peneliti melakukan penelitian di Kota Cimahi, kini penelitian dilanjutkan di Kabupaten Bandung Barat untuk mencari tahu tentang jawaban atas rumusan masalah yang telah dinyatakan di bagian awal. 


\section{Keberadaan Pola Hubungan Patronase Dalam Birokrasi Pemerintahan Daerah Kabupaten Bandung Barat}

Organisasi pemerintahan daerah di Indonesia pada umumnya menggunakan struktur keorganisasian birokrasi yang ditandai dengan sifat hubungan antar pejabatnya yang birokratis (rasional, formal, impersonal, dan prosedural). Sifat hubungan itulah yang mudah dilihat atau dirasakan baik oleh para pejabatnya (birokrat) maupun orang luar. Pola hubungan birokratis ini merupakan pola hubungan yang dipandang normatif untuk digunakan sehingga pola hubungan lain dianggap -mengganggu. Karena itu, pola hubungan yang lain sepertinya tidak begitu jelas terlihat jika tidak diamati secara khusus karena relatif -disembunyikan.

Melalui penelitian ini pola hubungan lain yang ingin diketahui keberadaannya dalam kehidupan birokrasi pemerintahan daerah adalah pola hubungan patronase. Dengan perkataan lain, peneliti ingin memastikan -apakah ada pola hubungan patronase dalam birokrasi pemerintahan daerah di lokasi penelitian (dalam hal ini Kabupaten Bandung Barat) seperti halnya telah ditemukan di beberapa daerah lainnya di tanah air. Pertanyaan tersebut diajukan mengingat adanya pendapat Ten Dam (dalam Kausar, 2009:163) yang mengemukakan bahwa dalam birokrasi pemerintahan daerah telah terjadi hubungan yang mengabdi dan memperabdi (hubungan patronase). Hal itu senada dengan pendapat Mardiyanto sewaktu beliau menjabat sebagai Menteri Dalam Negeri RI tahun 2007-2009 (dalam Kausar, 2009:ix) bahwa budaya patron-klien yang terdapat di lingkungan birokrasi pemerintahan daerah merupakan realitas yang tak dapat dipungkiri.

Sebagaimana telah dibahas pada kajian pustaka bahwa menurut Legg (dalam Kausar, 2009:18), hubungan patronase atau hubungan patron-klien merupakan hubungan khusus yang bersifat pribadi berdasarkan kepentingan yang saling menguntungkan antar pelaku yang menguasai sumber daya yang tidak sama. Hubungannya bersifat vertikal hierarkis. Patron berada pada posisi lebih tinggi dari klien karena kekuatan sumber daya yang dimilikinya jauh lebih besar ketimbang sumber daya yang dimiliki klien.

Pola hubungan ini ternyata ada dalam birokrasi pemda KBB sebagaimana diterangkan oleh beberapa informan. Pada waktu wawancara, seorang informan dari kalangan pejabat eselon IIb (Kepala Dinas) mengemukakan:

-Pola hubungan patronase seperti yang telah diterangkan peneliti dijumpai di lingkungan pemda kami. Dalam hal ini adalah hubungan khusus antara bapak 
Bupati dengan beberapa pejabat tertentu. Bapak Bupati memberikan perhatian khusus terutama melalui pengembangan karier untuk menduduki jabatan pada eselon IV, III, dan II. Pegawai yang dekat dengan bapak Bupati dapat meningkat melebihi dari rata-rata yang lain. Contoh, ada seorang pejabat yang awalnya tidak punya jabatan struktural, kemudian diangkat menjadi Kadis (eselon IIb) karena pada masa pencalonan turut andil menyukseskan kemenangan bapak Bupati. Namun demikian, pengembangan karier pegawai oleh bapak Bupati tidak dilakukan secara membabi buta. Beliau selalu mengaitkannya dengan kualitas perilaku dan kinerja ybs. Apabila terjadi ada pegawai yang telah dipromosikan tetapi perbuatannya buruk menurut penilaian umum, maka beliau segera menurunkannya kembali.

Dari keterangan ini peneliti mempunyai pengetahuan bahwa pola hubungan patronase dalam birokrasi pemerintahan daerah KBB memang ada. Tanda yang mudah diketahui tentang adanya hubungan tersebut adalah penempatan pejabat-pejabat yang diberi perhatian khusus pada posisi-posisi strategis terutama jabatan-jabatan struktural.

Informan lain dari kalangan pejabat eselon III/b (Kepala Bidang) mengemukakan hal yang sama:

-Saya mengetahui bahwa di pemda KBB ada hubungan patronase antara pejabat dengan bawahannya. Hubungan yang paling mudah diketahui adalah hubungan antara bapak Bupati dengan pegawai pemda tertentu yang dekat dengan beliau. Hubungan antar pejabat lainnya sangat sukar untuk dikenali. Keberadaan hubungan tersebut dapat terlihat dari pengembangan karier. Pegawai yang dekat diposisikan pada jabatan-jabatan yang dianggap strategis.

Senada dengan informasi ini, informan dari pejabat eselon III/a mengemukakan:

-Saya mengetahui bahwa di pemda $\mathrm{KBB}$ ada hubungan patronase antara pejabat dengan bawahannya, dalam hal ini yang mudah diketahui adalah hubungan bapak Bupati dengan pejabat tertentu. Hal itu ditandai dengan adanya pengembangan karier terutama pada eselon II (lebih dari $50 \%$ ) dan III (di bawah $20 \%$ ). Walaupun demikian, dalam mempromosikan pegawai yang tergolong kliennya tersebut, bapak Bupati sedapat mungkin menyesuaikannya dengan norma administrasi kepegawaian. Apabila setelah dipromosikan pejabat tersebut berbuat sesuatu yang buruk, maka beliau menindaknya a.l dengan menggesernya ke jabatan fungsional.

Keterangan selanjutnya diperoleh dari informan pejabat eselon II/b di lingkungan sekretariat daerah. Ia mengemukakan:

- Saya mengetahui bahwa di pemda KBB ada hubungan patronase antara pejabat dengan bawahannya, dalam hal ini bapak Bupati dengan pejabat tertentu. Hal itu ditandai dengan adanya pengembangn karier pejabat tertentu terutama di eselon II (lebih dari $75 \%$ ) dan III (di bawah $20 \%$ ). Contohnya ada pejabat gol IVa yang kemudian didudukkan dalam jabatan eselon IIb. Namun 
demikian, dalam mempromosikan pegawai yang berada pada jalur patronase, Bupati sedapat mungkin menyesuaikannya dengan norma administrasi kepegawaian, antara lain digodog dahulu oleh Baperjakat.

Dari keterangan beberapa informan tersebut, peneliti memperoleh pengetahuan sebagai berikut:

1) Dalam birokrasi pemda $\mathrm{KBB}$ terdapat hubungan patronase antara Bupati dengan pegawai pemda tertentu.

2) Keberadaan hubungan patronase antar pejabat lainnya sukar atau tidak dapat diketahui.

3) Tanda yang dapat dikenali dengan mudah tentang keberadaan hubungan patronase antara Bupati dengan pegawai pemda tertentu adalah adanya pengembangan karier yang dilakukan melalui proses khusus. Pegawai yang tergolong klien lebih diprioritaskan dalam menduduki jabatan struktural pada eselon IV, III, dan II.

\section{Latar Belakang Terjadinya Pola Hubungan Patronase Dalam Birokrasi Pemerintahan Daerah Kabupaten Bandung Barat}

Dalam bagian terdahulu telah disinggung tentang pendapat Kingsley Davis (dalam Thoha, 2014:64) bahwa di dalam suatu masyarakat manusia selalu terdapat double reality. Di satu sisi ada sistem normatif yang mengikat manusia untuk melakukan apa yang seharusnya dilakukan, tapi di sisi lain ada tatanan faktual (factual order) yang juga mengaturnya. Karena itu, jika dikaitkan dengan pendapat tersebut, bisa jadi pola hubungan patronase yang hadir dalam birokrasi pemerintahan dapat berlatar-belakang tatanan faktual yang hadir dengan sendirinya akibat dari kebutuhan para pejabat untuk saling menguntungkan satu sama lain. Jika kedua belah pihak tersambung, maka norma kerjasama-'pun hadir dengan sendirinya untuk dipedomani. Norma tersebut berasal dari nilai bersama yang dianutnya, paling tidak nilai saling menolong' walaupun di luar itu ada bingkai formal berupa pola hubungan berdasarkan karakteristik struktur organisasi di mana mereka bekerja.

Dalam kaitannya dengan itu, pertanyaan yang kemudian ingin dicari jawabannya ialah -hal apa yang melatar-belakangi pola hubungan patronase dalam birokrasi pemda KBB. Jawaban atas pertanyaan tersebut dapat diperoleh dari keterangan beberapa informan berikut. 
Informan dari kalangan pejabat eselon IIIa mengemukakan:

-Para pejabat yang diberikan perhatian khusus itu adalah mereka yang pernah mendukung keberhasilan bapak Bupati pada masa pencalonan kepala daerah periode kesatu dan kedua, mereka yang dipandang berkinerja baik dan loyal kepada bapak Bupati, atau mereka yang turut membantu bapak Bupati dalam penyuksesan urusan-urusan khusus, misalnya penguatan kerjasama pemda dengan pihak luar.

Keterangan tersebut memberi pengetahuan kepada peneliti bahwa salah satu faktor yang melatar-belakangi hubungan patroase bupati dengan pejabat tertentu adalah faktor politik dalam hal ini pilkada langsung yang telah dua kali diselenggarakan di KBB yaitu tahun 2013 dan 2017.

Pada masa pencalonan, calon bupati dibantu oleh para anggota tim sukses untuk memenangkannya. Pada masa sebelumnya (sebelum keluar UU No. 22 tahun 1999 tentang Pemerintahan Daerah), para birokrat tidak terlibat atau dilibatkan dalam upaya pemenangan calon karena kepala daerah dipilih oleh DPRD. Tetapi setelah masa dimulainya pilkada langsung (setelah keluar UU No. 22 tahun 1999 tentang Pemerintahan Daerah) sampai sekarang, para birokrat banyak yang dilibatkan atau melibatkan diri. Keadaan ini diwarnai oleh beberapa kepentingan. Di satu sisi, pihak calon berusaha untuk meraih simpati para birokrat karena sangat disadari potensi birokrat begitu besar terutama melalui pekerjaannya yang akan dapat mempengaruhi warga pemilih. Karena itu, birokrat-birokrat tertentu direkrut untuk menjadi anggota tim sukses secara -terselubung, tertutup, atau tersembunyi, karena peraturan perundang-undangan melarang PNS memihak pada salah satu calon (harus netral). Di sisi lain, para PNS tertentu merasa terpanggil/tertarik untuk ikut aktif menjadi anggota tim sukses karena alasan subyektif atau alasan obyektif.

Alasan subyektif berkenaan dengan upaya untuk menunjang pengembangan kariernya di masa yang akan datang (jika calonnya terpilih). Sedangkan alasan obyektif, berupa kepentingan untuk memilih calon kepala daerah yang dinilai layak untuk memimpin daerahnya karena integritas dan kapabilitasnya. Setelah calon bupati ternyata terpilih dan dilantik, bupati merasa -berhutang budi kepada birokrat yang sungguh-sungguh telah membantunya. Balas budinya tersebut diwujudkan dengan pemberian perhatian khusus antara lain berupa pengembangan karier birokrat yang bersangkutan (promosi). Dengan demikian dalam hubungan ini terjadi transaksi berupa kebaikan dibalas dengan kebaikan. Dukungan politis dari birokrat tertentu pada waktu pencalonan dirasakan sebagai suatu kebaikan bagi bupati terpilih, dan karena itu 
bupati membalas kebaikannya itu dengan perhatian khusus berupa peningkatan karier atau bentuk lainnya.

Senada dengan keterangan itu, informan lain (pejabat eselon IIb) mengemukakan:

-Latar-belakang yang mudah diketahui menyebabkan adanya hubungan patronase adalah pilkada langsung. Birokrat tertentu yang membantu pemenangan Bupati pada masa pencalonannya mendapat perhatian khusus dari Bupati bersama tim suksesnya. Kebanyakan dari mereka berada pada eselon 3 dan 4. Selain pilkada, Bupati adalah sosok yang berkepribadian low profile dan bijaksana. Beliau adalah orang Sunda yang sangat memelihara dan cenderung mengekspresikan nilai-nilai ketimuran. Karena itu, para pejabat tertentu walaupun tak terlihat membantu dalam pencalonannya tetapi jika dapat memperlihatkan perilaku dan kinerja yang baik oleh beliau kariernya diperhatikan.

Dari informan tersebut, peneliti mengetahui adanya faktor lain selain pilkada yaitu -kinerja pegawai. Walaupun pegawai yang dimaksud bukan pendukungnya pada masa pilkada, tetapi jika memperlihatkan kinerja yang dinilai baik oleh Bupati, maka Bupati mempromosikannya.

Dalam kaitannya dengan hal ini, seorang informan dari eselon IV/a (Kasubbag) menerangkan: -Saya tidak membantu menyukseskan bapak Bupati dalam pilkada dan saya merasa tidak mempunyai kedekatan khusus dengan beliau. Tetapi saya telah berusaha bekerja dengan sebaik-baiknya menurut tupoksi.

Senada dengan itu informan dari kalangan eselon III/a mengemukakan:

-Tidak dapat dipungkiri bahwa hubungan patronase dalam birokrasi pemda KBB itu ada terutama hubungan Bupati dengan pejabat tertentu. Sayapun mungkin termasuk pejabat yang ada dalam jalur hubungan tersebut karena kedekatan dengan Bupati sejak lama, termasuk ikut menyukseskan pemenangan beliau dalam dua kali pilkada. Selain karena pilkada, menurut saya hubungan patronase itu ada juga karena faktor lain yaitu prestasi kerja dan budaya untuk menghormati dan menaati atasan dari diri pegawai itu sendiri. Dengan sikap itu, Bupati memberi perhatian seperti kepada birokrat yang mendukung pencalonannya.

Keterangan informan ini menguatkan teori ketertarikan yang dikemukakan Donald E. Allen, Rebecca F. Guy, dan Charles K. Edgley (dalam Ahmadi, 1999: 229) teori kognitif, teori penguatan, dan teori interaksionis. Menurut teori kognitif, ketertarikan seseorang dengan orang lain pada saat awal disebabkan oleh adanya proses akal, yaitu adanya persetujuan dasar dan kesamaan pandangan tentang orang lain, tempat dan benda. Menurut teori penguatan, seseorang tertarik oleh orang lain pada 
saat awal disebabkan oleh hadiah atau penghargaan yang diterimanya. Sebaliknya, ia tidak tertarik bahkan menolak jika orang lain memberi hukuman atau sesuatu yang bersifat menghina. Menurut teori interaksionis, seseorang akan tertarik oleh orang lain karena ada sesuatu yang saling menguntungkannya. Ketertarikan antar orang-orang dalam pergaulan sosial akan menentukan rasa kebersamaannya. Semakin kuat ketertarikan, semakin kuat rasa kebersamaannya yang ditandai antara lain dengan keintiman, pengertian, kepercayaan, kerja sama dan saling menyayangi.

Dari berbagai keterangan para informan tersebut, peneliti menyimpulkan bahwa pola hubungan patronase antara Bupati dengan pegawai pemda KBB tertentu dilatarbelakangi oleh adanya beberapa faktor, yaitu:

1) faktor politik berupa penyelenggaraan pilkada langsung,

2) faktor budaya untuk saling menitipkan di antara kedua-belah pihak, dan

3) faktor kinerja pegawai yang membuat bupati merasa tertarik untuk mengembangkan kariernya.

\section{Dampak Keberadaan Pola Hubungan Patronase Dalam Birokrasi Pemerintahan Daerah terhadap Kinerja Pemerintah Daerah}

Telah disinggung di bagian terdahulu bahwa menurut sebagian kalangan, keberadaan pola hubungan patronase dalam birokrasi pemda dikhawatirkan dapat mengganggu kinerja pemda. Namun kalangan lain berpendapat bahwa justru pola hubungan patronase dapat mendorong kekompakan kerja untuk menguatkan capaian kinerja pemda. Karena itu, pertanyaan lainnya ialah -apakah keberadaan pola hubungan patronase tersebut mengganggu kinerja pemerintah daerah.

Guna menjawab pertanyaan tersebut peneliti bertanya kepada beberapa informan. Salah seorang informan dari kalangan pejabat eselon IVa (Kasubbid) mengemukakan:

-Pak Bupati sangat menekankan kinerja semua pegawai. Contohnya tentang kinerja pengelolaan keuangan, proyek-proyek fisik dll. Karena pengembangan karier dilakuan melalui Baperjakat, maka hubungan patronase dirasakan tidak mengganggu pencapaian kinerja pemda. Senada dengan keterangan itu, informan lain dari pejabat eselon IIIb (Kepala Bidang) mengemukakan: -Pak Bupati sangat menekankan agar kinerja semua pegawai sesuai dengan standar. Baliau tidak mau mepromosikan pegawai sekalipun dekat dengannya tanpa memperhatikan kelayakan agar tidak berpengaruh buruk pada kinerja Pemda. 
Informan dari kalangan pejabat eselon IIIa (Sekretaris Badan) mengemukan hal yang sama:

-Saya berpendapat bahwa hubungan patronase dapat menutup kekurangan pola hubungan birokrasi karena adanya sifat humanis.' Selain itu, keberadaan pola hubungan patronase mempunyai dampak positif antara lain berupa kehati-hatian para pejabat lainnya untuk bekerja secara baik dan loyal kepada pimpinan, karena takut dilaporkan kepada pimpinan jika berbuat sesuatu yang tidak sejalan dengan pimpinan. Selain itu, pimpinan sering mengarahkan tentang cara kerja pegawai yang -tepat waktu, tepat biaya, dan tepat mutu.

Dari keterangan ketiga informan tadi, peneliti mempunyai kesan bahwa walaupun hubungan patronase itu ada dalam birokrasi pemda KBB, namun Bupati tidak mau menempatkan kliennya dalam posisi strategis jika tidak memenuhi kriteria yang ditentukan oleh norma kepegawaian. Hubungan patronase juga tidak dengan sendirinya membebaskan pegawai yang menjadi klien Bupati untuk bekerja semaunya. Mereka yang tadinya merupakan klien, karena setelah dipercaya menduduki posisi penting ternyata berkinerja buruk, oleh Bupati -ditindak dengan cara memindahkannya ke posisi yang tidak begitu strategis. Dalam kaitan dengan ini informan tadi mengemukakan:

-Dalam mempromosikan pegawai yang berada pada jalur patronase, Bupati sedapat mungkin menyesuaikannya dengan norma administrasi kepegawaian. Apabila setelah pejabat yang dipromosikan tersebut berbuat sesuatu yang buruk, maka Bupati menindaknya a. 1 dengan menempatkan ybs pada jabatan yang diapandang kurang strategis.

Berbagai keterangan informan tersebut menimbulkan kesan kepada peneliti bahwa Bupati -mengelola hubungan patronasenya dengan hati-hati sehingga tidak mengganggu kinerja pemda. Terkait dengan hal itu, berikut ini disajikan beberapa data kinerja pemda KBB berdasarkan dokumen Bappelitbangda (Badan Perencanaan dan Penelitian Pembangunan Daerah), selama periode 2013-2016. Pertama, tentang capaian IPM (Indeks Pembangunan Manusia) dari tahun 2013 sebesar 74, 63, tahun 2014 sebesar 74,92, tahun 2015 sebesar 75,35, dan tahun 2016 sebesar 75,79. Jika mengacu pada kategorisasi status IPM menurut UNDP, maka IPM Kabupaten Bandung Barat selama tiga tahun terakhir termasuk dalam kategori -kelompok tinggi, yakni kelompok daerah dengan nilai IPM berkisar 70-80. Adapun capaian masing-masing komponen IPM cukup bervariasi. Status indeks kesehatan termasuk dalam kategori 
-kelompok tinggi (capaian 70-80), status indeks pendidikan sudah masuk dalam kategori -kelompok sangat tinggi (capaian di atas 80), sedangkan status indeks daya beli masih dalam kategori -kelompok sedang (capaian 60-70).

Data IPM tersebut mengindikasikan terjadinya perbaikan kualitas pembangunan manusia Kabupaten Bandung Barat dari sisi kesehatan, pendidikan dan daya beli penduduk beberapa tahun terakhir.

Kedua, tentang pertumbuhan ekonomi daerah. Dari dokumen Bappelitbangda diketahui bahwa LPE (Laju Pertumbuhan Ekonomi) yang ditunjukkan oleh laju kenaikan/penurunan PDRB berdasarkan harga konstan tahun 2000. LPE tahun 2014 sebesar 5,68\%, menurun pada tahun 2015 menjadi 5,18 tetapi meningkat kembali pada tahun 2016 menjadi 5,56\%. Sedangkan pendapatan perkapita terus meningkat. PDRB perkapita atas dasar konstan tahun 2000 yang menggambarkan nilai tambah riil penduduk Kabupaten Bandung Barat di tahun 2014 adalah sebesar 6.271.626,14 rupiah, PDRB per kapita tahun 2015 sebesar 6.515.769,00 rupiah dan tahun 2016 mencapai 6.798.713,21,- rupiah atau tumbuh sebesar 4,34 persen dibandingkan tahun sebelumnya.

Ketiga, tentang prestasi umum lainnya seperti Penghargaan "The Best Performance Infrastructure" Tingkat Nasional Tahun 2016, penghargaan Terbaik Listrik Masuk Desa se-Jawa Barat Tahun 2016, dan penghargaan bagi Badan Kepegawaian dan Pengembangan Sumber Daya Manusia tahun 2017 Kategori Kepatuhan dan Kualitas Tata Kelola Seleksi Tinggi dari Komisi Aparatur Sipil Negara Republik Indonesia.

Dari analisis terhadap keterangan beberapa informan dan data sekunder tadi, peneliti berkesimpulan bahwa -keberadaan pola hubungan patronase dalam birokrasi pemerintahan.

\section{Kesimpulan Dan Saran}

\section{Kesimpulan}

Bertolak dari rumusan masalah, tujuan penelitian dan pembahasan hasil penelitian, peneliti menyimpulkan hal-hal sebagai berikut:

1) Pada birokrasi pemerintahan daerah Kabupaten Bandung Barat terdapat pola hubungan patronase antara Bupati (sebagai patron) dengan para pejabat tertentu (sebagai klien) yang diketahui dari pengembangan karier. Bupati sebagai patron, dengan segala kewenangan jabatan yang ada padanya memberikan perhatian 
khusus kepada bawahan yang menjadi kliennya dalam pengembangan karier berupa promosi pada jabatan-jabatan tertentu yang dipandang strategis. Sedangkan, pegawai tertentu sebagai kliennya memberikan dukungan, loyalitas, dan pengabdian kepada bupati.

2) Faktor-faktor yang melatar-belakangi terjadinya pola hubungan patronase dalam birokrasi pemerintahan daerah Kabupaten Bandung Barat yaitu pertama adalah faktor politik berupa penyelenggaraan pilkada langsung, kedua adalah faktor budaya untuk saling menitipkan di antara kedua-belah pihak, dan ketiga adalah faktor kinerja pegawai yang membuat Bupati merasa tertarik untuk mengembangkan kariernya.

3) Keberadaan pola hubungan patronase dalam birokrasi pemerintahan daerah KBB tidak berdampak negatif terhadap capaian kinerja pemda.

Beranjak dari kesimpulan hasil penelitian sebagaimana dikemukakan tadi, peneliti mengajukan konsep yang dirumuskan dalam proposisi: "pola hubungan patronase dalam birokrasi pemerintahan daerah tidak berdampak negatif terhadap capaian kinerja pemerintah daerah, jika kepala daerah dapat mengelolanya secara hati-hati."

\section{Saran}

Penelitian ini memiliki keterbatasan antara lain bahwa konsep baru yang diangkat, masih merupakan hasil penelitian secara kasuistis pada konteks lingkungan birokrasi pemerintahan daerah di Kabupaten Bandung Barat. Pola hubungan patronase yang ditelitipun hanya pola hubungan patronase yang dilakukan bupati dengan pejabat tertentu. Sedangkan hubungan patronase antar pejabat lainnya, seperti wakil bupati dengan pejabat tertentu, sekda dengan pejabat tertentu, dan antar pejabat-pejabat lainnya belum diteliti. Selain itu, tanda keberadaan hubungan patronase yang diteliti karena mudah kenampakannya adalah dalam hal pengembangan karier pihak klien. Tanda-tanda lainnya belum diungkap melalui penelitian ini. Karena itu, agar hasil penelitian ini memiliki transferabilitas yang lebih kuat dan konsep baru dari penelitian yang bertema serupa dengan penelitian ini bertambah, maka disarankan agar dilakukan penelitian yang sejenis di daerah-daerah lainnya. 


\section{DAFTAR PUSTAKA}

Ahmadi, H. Abu, 1999, Psikologi Sosial, Cetakan kedua,Jakarta: Rineka Cipta.

Albrow, Martin, 1996, Bureaucracy, terjemahan M. Rusli Karim dan Totok Daryanto, Yogyakarta: PT Tiara Wacana Yogya.

Badan Perencanaan dan Penelitian Pembangunan Daerah Kabupaten Bandung Barat, 2016, LKPJ 2016 Pemda Kabupaten Bandung Barat.

Blau, Peter M, and Meyer, Marshall W, 1987, Bureaucracy in Modern Society, terjemahan Gary R. Yusuf, Jakarta: UI-Press.

Dwiyanto, Agus, dkk., 2002, Reformasi Birokrasi Publik Di Indonesia, Yogjakarta: Pusat Studi Kependudukan dan Kebijakan Universitas Gajah Mada.

Iver, Mc, 1992, Jaring-Jaring Pemerintahan Jilid II, terjemahan Laila Hasyim, Jakarta: Rineka Cipta.

Kausar, 2009, Sistem Birokrasi Pemerintahan Di Daerah Dalam Bayang-Bayang Budaya Patron-Klien, Bandung : Alumni.

Luthans, Fred, 1995, Organizational Behavior, Seventh Edition, Singapore: McGrawHill Book Co.

Mintzberg, Henry, 1983, Structure In Five : Designing Effective Organizations, Prentice-Hall International, Inc., London.

Ndraha, Taliziduhu, 2003, Kybernology (Ilmu Pemerintahan Baru) Jilid 1 dan 2, Jakarta: Rineka Cipta.

Ndraha, Taliziduhu, 2001, Ilmu Pemerintahan (Kybernology), Program Pascasarjana S2 dan S3 Ilmu Pemerintahan Kerjasama IIP-UNPAD, Jakarta.

Prent, Adisubrata, dan Poerwadarminta, 1969, Kamus Bahasa Latin-Indonesia, Yogyakarta: Kanisius;

Rasyid, Ryaas M, 2000, Makna Pemerintahan, Jakarta, Mutiara Sumber Widya.

Robbins, Stephen, P, 1987, Organization Theory, Structure, Design, And Application, New Jersey-USA: Prentice-Hall, Englewood Cliffs.

Roosadijo, Marmin Martin, 1982, Ekologi Pemerintahan Di Indonesia, Bandung: Alumni.

Setiono, Budi, 2002, Jaring Birokrasi, Tinjauan Dari Aspek Politik dan Administrasi, Bekasi: Gugus Press. 
Sufianto, Dadang, 2016, Etika Pemerintahan Di Indonesia, Bandung: Alfabeta.

Thoha, Miftah, 2014, Birokrasi \& Dinamika Kekuasaan, Jakarta: Prenadamedia Group. 